\title{
BLACK FEMINISM REIMAGINED: AFTER INTERSECTIONALITY
}

\author{
NASH, Jennifer C. Durham: Duke University Press, 2019, 170 p.
}

Jennifer C. Nash, in her Black feminism reimagined: after intersectionality ${ }^{1}$ (2019), tackles issues surrounding the concept of intersectionality from a fresh and nuanced perspective that offers a sharp and critical look into one of the key concepts of black feminism and its contemporary applications. In her introduction, Nash orients the readers to think of the feminism of black feminism, not as a singular noun. She proposes this as a way to prevent one-dimensional thinking. However, she employs the term in the singular form throughout the book, which also deals primarily with the United States context, rather than balancing such attention with third world manifestations of black feminisms as well.

An important contribution is made when the scholar proposes a way to reframe the making of black feminist theory. She defines her approach by regarding "black feminism as an affective project - a felt experience - as much as it is an intellectual, theoretical, creative, political, and spiritual tradition" (p. 3). By drawing upon the plural nature of black feminism, Nash complicates the idea of academia as a safe site for the fostering of feminist thought by questioning the ways in which black women's bodies are still absent and disappearing from such spaces. It becomes a paradox, then, that the academy is calling for intersectional scholars while using (or misusing) intersectionality for institutional good image. Such process facilitates systemic violence against black women (p. 19) and the site of academic knowledge production, then, becomes the place where black women's labor is disavowed (p. 64).

For this critique of violence against black women and the disavowal of their experiences, the reader outside of the U.S. academic environment could benefit from clearer examples aimed at highlighting how this erasure and resulting violence is happening in the U.S. context, as this reflection might contribute to an evaluation on how institutions are applying intersectionality to the politics of academic workspaces in transnational spaces.

When it comes to the transnational picture, though, Nash affirms: "the global university's lure and promise have not been attached to the idea of transnational feminism in the same way that ideas of diversity and inclusion have been yoked to intersectionality" (p. 95). Besides, she worries about the way in which intersectionality is often about looks and performativity, because "intersectionality is also thought to be performed by black female scholars whose very embodied presence is thought to be, in and of itself, intersectional" (p. 98).

1 NASH, Jennifer C. Black feminism reimagined: after intersectionality. Bogart: Duke University Press, 2019.

Eliza de Souza Silva Araújo

Doutoranda PPGL/UFPB. E-mail: edessaraujo@gmail.com 
One action Nash urges as a way to reimagine intersectionality is the detachment of the study and application of theory from limiting the concept of intersectionality to a discussion around origin stories. She highlights the importance of The Combahee River Collective Statement, as well as the writings of Frances Beale, Deborah King, Kimberlé Crenshaw and Patricia Hill Collins - whose scholarship were of utmost importance for the conceptualization and epistemological application of the concept to black women's everyday lives, but suggests intersectionality reaches a way broader spectrum when scholars do not act defensively and focus on amplifying the reach of intersectional thought, rather than limit it to the right person or group to credit for its naming.

To swim against this wave, Nash proposes methods of evaluation and rescue, when dealing with intersectionality. As a theorist, she aims at identifying the problems in the theory and saving it from misuse. This is a way, according to her, that we can read intersectional thought with commitment and care in order to "practice care for intersectionality, to nurture it, to cultivate it, to treat it with respect and affection" (p. 59).

On the chapter entitled "Surrender", Nash draws attention to the way in which the idea of intersectionality was strengthened through discussions and conflict, happening in conferences; occasions where conversations about it were encouraged. At this point she talks about the National Women's Studies Association (NSWA), founded in 1977, which was responsible for annual conferences where binary tensions were put to test. Such occasions generated a pressure for the organization to reconceptualize their mission and structure. Because of the gathering of scholars and community members coming from all walks of life and all around the world, and because of the conversations they were allowed to have on such meetings, Nash understands there was a push that amplified the conversation in these spaces where intersectionality was understood as "a challenging conversation worth having" (p. 93). In these events, questions of the global started to be discussed, bringing transnational feminism into play. This is a chapter where Nash offers more of her own concepts and methods to justify the need for reimagining intersectionality, which can happen through an act of surrendering, as the title of this chapter suggests. She says that

Intersecionality used the figure of the black woman as a metaphor for the most marginalized subject, as a way of conceptualizing how structures of domination work to wound and oppress, and suggested feminism needed to build a theory of gender, race, sexuality, class, and nation complex enough to contend with this particular subject's distinct position. In other words, intersectionality used black woman to map what the discipline could aspire to be -- a critical practice deeply attentive to complexity and particularity (p. 92). 
It is interesting to think of intersectionality as an analytics that was brought to the table and then amplified through conversation and community. In this sense, intersectionality is understood as a more vast terrain, a plural space of possibility, which truly reflects the values of black feminism. Moreover, Nash suggests an antiterritorial approach to the term: she believes in moving the focus from the black woman, to a further understanding of the experiences of the diaspora, which accounts for the women of color, in transnational spaces. Nash believes then, that intersectionality needs to move beyond the category of the black woman. What Nash defends is a thought project, and also a political project, because it approaches the appeal to coalitions, which could address the current crisis in intersectionality.

The theorist believes intersectionality must continue to interrogate, owing to black women's plural ethnicities, queerness, class distinctions, etc. A way to revive the term, according to her, is to feel it. Nash believes in the felt experience as the result of a combination of love and law. She talks about a "love-politics" (p. 114) and about the radical potential of love. She believes in a "loving engagement" (p. 113) with theory, that opens space for a reflection and critique, for commitment and care. Love, in Nash's analysis, can expand the community relations to become an orienting force of law and politics. She concludes that "we need not consider lovepolitics and intersectionality as in opposition, that intersectionality is itself a black feminist articulation of love, and that law can be a(nother) site of black feminism's love-politics" (p. 115).

252 Nash's book ends with a chapter named CODA. some of us are tired, in a reference to the black feminist scholarly collection But some of us are brave, from 1982, organized by Hull, Bell-Scott and Smith. In this section, the scholar brings emphasis to the effort made by black women to prevent Trump's election. Nash pushes against the tendency to turn to black women as the saviors of US politics, because she believes this is not helping actual political change. She also pushes against the notion that black women saved feminism because this narrative is understood to produce defensiveness, territoriality and determine black women, in a way, own intersectionality. Nash believes that the way black feminism is thriving and embracing new debates and challenges, the same should happen to the analytics of intersectionality. A way to start? Black feminists must stop engaging in intersectionality wars and start to broaden the discussion from the issues of black woman, to the issues of women of color, in the U.S. and transnationally. Black women must embody love while working with this analytics, as this is the place where all solidarity and revolution started to shape. 